\title{
The Representation of Human Rights and Economic Positions in Cuba
}

\author{
SZABÓ Máté Csaba ${ }^{1}$
}

\begin{abstract}
This article describes the more than a decade-long process, during which Cuba, having lost its economic stability, has been economically moving closer to EU countries that are investing more and more in tourism and other industries. Although in many areas a shift towards a market economy can be observed in Cuba, these measures have not been accompanied by political reforms and guarantees of basic human rights that are considered fundamental values in the European Union. The article introduces the efforts of the Cuban opposition and organizations over the last twenty years, and describes the steps, with which the European Union has supported and recognized those who are fighting for freedom and rights in Cuba. Through these actions the European Union makes it clear that besides improving economic relations, the EU emphasizes and monitors the political systems of its trading partners, expecting them to guarantee certain basic rights.
\end{abstract}

The decision of the European Parliament, regarding who the Sakharov Prize would be awarded to, was preceded by great expectations. ${ }^{2}$ In 2010, Guillermo Fariñas received the high-ranking prize, which is awarded to exceptional personalities, groups, or organizations fighting against oppression and fighting for freedom of thought. ${ }^{3}$ The result surprised many, as this has been the third occasion since 2002 for a Cuban person or organization to win the award. The two other nominees were Birtukan Mideska, an Ethiopian female politician, and an Israeli group, called Breaking the Silence.

It is worth considering and observing the background of the decision and why a Central- American country can be so exceptionally important for the European Union, as it might seem that the Caribbean area does not belong to the primary political and economic sphere of interest; furthermore, unfortunately, there are plenty of political systems in the world where freedom of speech and freedom of opinion are significantly restricted. In order to understand the prevailing state of affairs concerning human rights, it is worth looking back on the efforts of the last two decades.

Although, the changes in the political systems, taking place in 1989 and 1990, and the collapse of the Soviet Union left the insular country without ideological, and even worse, without economic support, the aging Caribbean dictator, Fidel Castro, adhered to his ortho- dox communist views, so any kind of opening or détente was out of the question. After losing the most important donor to the economy, the economic blockade dictated by the United

1 xmate@freemail.hu

2 http://www.europarl.europa.eu/aboutparliament/en/00f3dd2249/Sakharov-Prize-for-Freedom-of-Thought.html (downloaded: 0508 2013)

3 http://www.europarl.europa.eu/sides/getDoc.do?pubRef=-//EP//TEXT+IM-PRESS+20101001FCS84570+0+ $\mathrm{DOC}+\mathrm{XML}+\mathrm{V} 0 / / \mathrm{EN} \&$ language $=\mathrm{EN}$ (downloaded: 0508 2013)

SZABÓ Máté Csaba: The Representation of Human Rights and Economic Positions in Cuba

States and the additional Toricelli and Helms-Burton Laws almost asphyxiated Cuba; in the 90s, the Cuban economy lived through years of crisis, and it cannot be said that the country has managed to recover from the trauma yet. Supply disruptions came to stay, the infrastruc- ture declined, production ceased in many former sections; moreover, sugar production, the greatest pride of the country, reached the worst level experienced. Mechanical power was replaced by animal power and power supply declined to 4-6 six hours per day in cities. The inhabitants suffered from illnesses caused by malnutrition due to food shortage, food-ra- tioning, and problems connected to distribution. The state of public health also started to decline significantly, and it is easy to understak 3 the bleak vision of the future in this society if we regard the great number of abortions. (Anderle, 2004)

The system found the only breakout point, which ensured its survival, in tourism. In this area, Cuba has exceptionally favorable conditions, and the significant traditions of the industry go back to before the revolution. Fidel Castro's brother, Raul Castro, who is ruling the country now, played a key role in the construction of the economic program, which made sedentation possible for foreign joint-venture companies in some separated areas. (Latell,

2008) After the initial distrust, a significant capital-inflow began, and by the end of the 90s, Canadian, partially Mexican, but mainly a large number of European (Dutch, Spanish, and Portuguese) investments turned up on the island. During the 2000s, strategic industries, such as telecommunication, transportation, and sugar production, also obtained large-scale in- vestments.

It is important to emphasize that from the War of Independence to Fidel Castro's takeover, Cuba was counted as part of the American economic sphere, and from the inevitable fall of Communism, the economic groups that belonged to the United States wanted to ascribe Cuba to their own sphere of interest again. However, because of the embargo, they 
excluded themselves from the economic opportunities offered by the island, a factor not taken into consideration up to the 90s, because the embargo-policy did not account for the opportunity that the communist political system and market-economy would be reconcilable. However, as a result of the foreign investments laws in 1995 , 360 jointventure companies were reg- istered, but there were some national societies and companies completely owned by foreign countries. Although, some American investment groups wanted to expand on the island, it was banned by their own political systems. (Leonard, 2004)

The American political and economic elite was forced to realize that the embargo policy instead of leading to the fall of the Cuban regime, excluding the American capital groups, made the occurrence of other foreign investors possible, who, using it as an "economic bridgehead," can break into the Central-American market, which had almost completely been led by American capital and American articles beforehand.

Observing it from this aspect, the birth of the 1996 law linked to Senators Helms and Bur- ton is not a coincidence; the law, in title, is about freedom and solidarity, but it primarily aims to make the position of joint-venture companies untenable. The law let the United States cancel its contract with any American company that maintains commercial relations with Cuba; moreover, if the company carried out trade with a Cuban company which had been an American company before the Cuban nationalization, (like most of the companies), then the American losers of nationalization can bring an action for damages against the company. A national wave of protest started against the law which, to the Cuban political elite's delight, was regarded as the manifestation of American's new imperialism.

SZABÓ Máté Csaba: The Representation of Human Rights and Economic Positions in Cuba

The loudest protesters emerged from the European Union; moreover the European Coun- cil declared in its 2271/96 regulation on November 22, 1996, a ban on the enforcement of the American law, which would allow for legal steps against American companies. (The Council of the European Union, 1996) The national scandal and the commercial war, which was thought to follow, did not happen: President Clinton and all his successors since then suspend the enforcement of the law in force every six months.

So, the Helms-Burton law did not achieve its purpose, but it is worth observing from which countries the highest number of investors have arrived in Cuba to date: besides China and Canada, there is Spain, Italy, the Netherlands, France, Great Britain, and Mexico, so it is obvious that some countries of the union managed to acquire significant economic positions in the area. The European Union became the most important commercial partner of Cuba; more than half of the foreign capital investments in Cuba arrive from the European Union. ${ }^{4}$

In the years leading to 2000, as a result of the huge investments, a high number of holiday resorts were built for Western tourists. The suffocating absence of currency seemed to get better, thanks to the tourists' dollars and Euros. (Buzás, 2002) So, Cuba was relieved for a while, but the Castro-clan had to stick to its ideological views in this situation and it would not yield ground for any kind of relief, so it took steps against opposition organizations as it had done before for decades. The most well-known human right organizations condemned Cuba many times, because it suppresses almost every thought of opposition, strictly regulat- ing and supervising every form of expression of opinion. In spite of all these circumstances, political dissidents have appeared in Cuba, of whom Oswaldo Payá was the most important and most significant.

Oswaldo José Payá Sardiñas was born to a deeply religious family, where he experienced the oppressiveness of Communist Cuba. It was a significant experience of his youth when he refused to carry out the command to transport prisoners of war to prison. He spent three years in labor camp for his disobedience, and his readiness to act based on his deep Catholicism became crystal clear then.

In 1988, he established the Christian Liberation Movement (Movimiento Cristiano Libe- ración) in Havana, which fights for political change and freedom with peaceful means. In

1992 and in 1997, he announced that he wanted to take the advantage of his rights ensured by the constitution of the communist state: he ran for election to the National Assembly of Popular Power. The political authorities managed to thwart him twice with administrative devices, as the election committees did not accept his nomination, although he had thousands of signatories who explicitly supported him.

As Anderle Ádám states, the emergence of the Catholic Church in political life was a new phenomenon in the 1990s. (Anderle, 2004) Its new journals, like Credo, Palabra Nueva, became the new forums of the Democratic

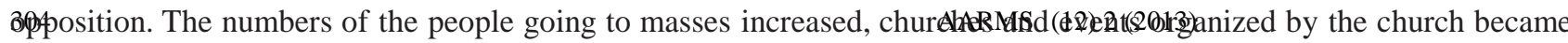
the stages of the actions of the opposition. The Catholic Church became a political alternative, especially af- ter the pastoral (letter) issued by the bishop in September 1993, which was addressed to the nation and to the Miami immigrants pleading of peace, unity and the search for a way out of economic and moral crisis. The Communist power reacted furiously and harshly.

4 http://lanic.utexas.edu/project/asce/pdfs/volume14/spadoni.pdf (downloaded: 0508 2013)

SZABÓ Máté Csaba: The Representation of Human Rights and Economic Positions in Cuba

Following the failure of 1997, one year later, Paya established the Valera Project named after Felix Valera, - a Cuban clergyman, who fought for the abolition of slavery and for the freedom of the colonies in the 19th century - 
with the Christian Liberation Movement. (Sweig, 2009) The Valera Project took advantage of article (88/9) of the Communist Consti- tution which says that 10,000 eligible civilians, who can be identified, can propose a bill to the national assembly. (The Constitution of the Republic of Cuba, 2002)

In fact, the bill was a political reform; according to it, the freedom of speech, the freedom of assembly, the freedom of religion, and the freedom of press have to be ensured in Cuba, and it also stood up for the release of prisoners and for the right to launch a business venture.

The Communist nomination committees did not accept the bill; moreover, they accepted a constitutional amendment which secures the immutability of the socialist nature of the state. As the Valera Project was received with extensive sympathy in the United States, the Cuban government wanted to give the impression that it had been a pre-planned action financed by the USA, and not a civil initiative. During the next few years, many of the signatories of the plan suffered abuses from the state, which forced many people to give false evidence. Paya continued his peaceful action and fought for freedom, and for social and economic reforms, his work was recognized by the European Parliament as Paya was awarded a Sakharov Prize in 2002. In the same year, an unprecedented collaboration took place between the Cuban opposition: in the Declaration of Todos Unidos (Everyone Together) in 2002, with more than

25,000 signatures, they proposed the plan to the National Committee.

This was too much for the state led by Castro, where verbal resistance against the govern- ment was regarded as a subversive action, and one could be sentenced to prison for 25 years because of it. During the "Black Spring" of 2003,75 activists of the opposition were detained and were sentenced to prison for 6 to 28 years due to their actions against national indepen- dence and territorial unity. Although Paya himself was not among those detained, two thirds of the journalists, librarians, political and civil-right activists, declared agents of the United States, suffered under the campaign, which aimed to destroy the Valera Project. Although the authorities hoped that they would manage to suppress the opposition and to eliminate the participants, they were mistaken, because the wives, mothers, and children of the prisoners brought their plight to the attention of national public opinion. The families carryied on the spirit of the opposition.

The "Ladies in White" (Damas de Blanco) became a spontaneous movement in 2004. It does not act as a political party, and it does not belong to any political organization. Women wearing white clothes as a symbol of innocence and charity acted like "the Mothers of Mayo Street" in Argentina, who became famous in the 1970s, because they wanted to be informed about their children who disappeared during the military dictatorship. ${ }^{5}$

"Ladies in White" assembled in Saint Rita's Church every Sunday, and after the ceremo- ny, they march down the $5^{\text {th }}$ Avenue of Havana peacefully and they spoke up for the release of their loved ones and for the imprisoned people in this insular country, all the while holding flowers. At first, they wrote letters to the Cuban authorities, but the authorities did not answer for decades. This was the first occasion that women marched in the streets of Cuba to protest against unjust imprisonments. One of the most serious actions against the "Ladies in White" was on March 20 in 2004, when the members of the Organization of Cuban Women attacked

5 http://www.humanrightsfirst.org/our-work/human-rights-defenders/cuba/the-ladies-in-white/ (downloaded: 0508 2013)

SZABÓ Máté Csaba: The Representation of Human Rights and Economic Positions in Cuba

and assaulted them. The members of the dissident group protested peacefully and asked for the immediate release of prisoners of the state. In spite of the threats and insults, "Ladies in White" still fights for the rights of Cuban prisoners and for the pride of the Cuban people.

Their peaceful protest, by which they ask for the immediate and unconditional release of prisoners of conscience and for justice, was awarded a shared Sakharov Prize by the Euro- pean Parliament in 2005. The EU, in answer to the imprisonment and the violation of human rights, reacted with the application of sanctions. Until 2003, the European Union contributed to the basic food and water supply in Cuba, which was hit by hurricanes, and with aid of almost 145 million Euros and to achieve other humanitarian goals. In regard to the state of human rights, it suspended the remittance of further support until the solution of other prob- lems, putting the government into a difficult situation. ${ }^{6}$

In spite of the imprisonments, Paya reckoned that the suppression of the government did not hold the opposition 306 rk back, as it was his firm belief that Cuban people need change without violence He started the National Dialogue in 2003, in which more than $12,000 \mathrm{Cu}$ - ban people living on and outside of the island shared their opinions and views about the future of Cuba. The experiences and proposals he acquired here were built into the initiative called "Program of All Cubans" which was announced by Paya and aims to contribute to peaceful and democratic change. The government reacted to every initiative angrily and dis- missively, but they did not dare to arrest Paya, due to his international recognition, although he is still subject to persecution and his exit requests are also refused.

The leader of the opposition, who is also nominated for the Nobel Prize, has been accused of being the agent of American interests and he was also said to be a paid agent of the Euro- peans, but what is even more surprising is that some immigrant Cubans tried to label him a Communist. Critics never forget to remark that the Sakharov Prize, in addition to the moral acknowledgement, also means 50,000 Euros for the awarded person. It goes without saying that none of the Cubans awarded got an exit visa to have the opportunity to go to the award ceremony.

Although many people hoped that the decisions made against the political prisoners would be revised, nothing happened for years, though the state has been led by Raul Castro, who is said to be a reformer, since 2006 . For the 
release of the prisoners to be put on the agenda by the communist power, a tragic event had to happen.

Orlando Zapata Tamayo was also convicted in 2003, but not as the member of the 75s. For he had been arrested before for "acts against the revolution," he had been organizing a protest from the beginning of his imprisonment, and he did not cooperate with his custodians, he was sentenced to prison for 6 years. In the $6^{\text {th }}$ year of his imprisonment, as a form of pro- test against the circumstances in prisons and because he was kept in prison among common criminals, he started his hunger strike in December, 2008. As a move against the government he also demanded that the Cuban prisoners of conscience should be kept in prison under circumstances that Fidel Castro enjoyed from 1953 when he was sentenced for the siege of Moncada barracks - this issue was distorted by the authorities, stating that the prisoner wanted to have a television during his hunger strike. The warders of the prison Kilo 7 in Camagüey did not ascribe great significance to the case. Orlando Zapata's condition wors- ened rapidly, especially after the inspectors tried to persuade him to stop his hunger strike

6 http://eeas.europa.eu/cuba/index_en.htm (downloaded: 0508 2013)

SZABÓ Máté Csaba: The Representation of Human Rights and Economic Positions in Cuba

with the withdrawal of water. The prisoner's weak body (after 23 days of starving) could not carry on the fight any morealthough recognizing the problem, they tried to feed him artifi- cially, on February 23 in 2010, and he died. (BBC, 2010)

Although Orlando Zapata Tamayo did not belong to the best known members of the op- position, he is now considered to be the greatest martyr of Cuba; however, the Cuban press did not write a word about his death for a long time, and when it became unavoidable, they tried to make him appear a common criminal. He successfully turned the attention of national public opinion towards the situation concerning human rights in the insular country of Cuba. Under the barrage of national critiques, the Cuban government started to formulate its inten- tion to arrange the situation of prisoners whom had been forgotten for decades.

The flame of revolt was taken over by the journalist Guillermo Fariñas, who was a psy- chologist, he also announced a hunger strike. Fariñas declared that he would hold on until the release of the 52 members of the group of $75 \mathrm{~s}$. As he was not a prisoner himself, the slow worsening of his condition could be seen at his home in Santa Clara - in the insular country and outside its borders. The Cuban government reacted furiously and with harsh critiques of the situation that got great publicity, but as a consequence of huge national pressure, the ne- gotiations started with the Church as a mediator. The communist leadership refused to admit that it would yield to the pressure; yet, on July 8 in 2010, Jamie Ortega, the bishop of Havana, declared that the prisoners of conscience would be released by the end of the year, so Fariñas stopped his hunger strike, which had been going on for 134 days. On hearing of the releases, many expressed their joy, prompting Cuba to further steps. (European Union, 2011)

It soon turned out, that there is no general amnesty, nor democratic progress. The pris- oners were released in smaller groups continuously, and most of them were transported to the airport to depart to Spain with their families. Because of the intervention of the Spanish minister of foreign affairs, Migual Maratinos, the dissidents got protected citizenship and work permits, and they were promised that Madrid would support them in the future. The physical and psychological state of people arriving to the capital of Spain was evidence of the cruel life in prison. Because of the wet cells, many had to live with serious and perma- nent health problems. Among the prisoners, there were people who had lost forty kilograms during the years. The ex-prisoners, in addition to their circumstances, also reported of cruel torture from the jailers; physical/ corporal punishments commonly happen in Cuban prisons, but they also apply psychological pressure very often; they reported a fellow prisoner who was not allowed to talk to anybody for months, his only comrades were rats and cockroaches. Some could not see the sun from their cells for months, while others were not allowed to turn off the lights.

Though the Cuban authorities expected that everybody would want to leave the country, and they would manage to send all the dissidents into exile, twelve people decided to stay in their mother country. The system has shown its true colors to those who decided to remain: it did not rescind the remaining part of their jail sentence, so, in theory, they could be called back to prison at any time; furthermore, they are subject to strict and permanent control. Sup- posedly, the protraction of the process of release until the spring of 2011 aimed to strengthen the feeling of uncertainty in the dissidents 12$) 2$ (2013)

At the same time, the Cuban government achieved an undesirable goal, that from the dec- laration until the release of the last prisoner, they were able to avoid the question of the Cuban state's concern for human rights. However in the fall of 2010, when the Sakharov Prize was

SZABÓ Máté Csaba: The Representation of Human Rights and Economic Positions in Cuba

awarded, and when it became obvious that Fariños would not get an exit visa, so - similarly to Oswaldo Paya and the group "Ladies in White" - he could not receive the award, more and more people started to question the willingness of the Communist state to change.

The European Union, following the serious damages caused by hurricanes, restarted the humanitarian cooperation and the dialog with the insular country on a ministerial level, and the primary aim of Cuba is to suspend the Common Position against Cuba, which has been applied since 1996 by the European Union after the releases. The aim of the Common Posi- tion, which is examined every six months, is to advance the fulfillment of democracy in the insular 
country and the respect of human rights. In Spain, many argued that the European Union, as an answer to the release of the dissidents, should abolish the Common Position, while taking over the lead and tightening the relationships with Cuba; all these triggered the resistance of the Cuban immigrants, dividing the member states as well.

Finally, the ministers of foreign affairs of the member states still maintained the Common Position; however, they asked Catherine Ashton, the High Representative for Foreign Affairs and Security Policy of the European Union, to carry on negotiations about commercial and political cooperation, raising the relationship between Cuba and the European Union to a bilateral level. Besides, the package deal of twenty million Euros for aid, a developmental contribution has been finalized, and cannot be withdrawn, from 2011 to $2013 .^{7}$ This will definitely be necessary, as the economy of Cuba needs huge reforms: after a fourteen-year- intermission, the $6^{\text {th }}$ Congress of the Communist Party was organized in April 2011 with the new economic model in the center.

At the same time, more people, primarily from the countries of the ex-communist block, expressed that they do not agree with the tightening of the relation between Cuba and the Eu- ropean Union until the radical improvement of the situation of human rights. (Wałęsa, 2010) They point to those events that happened on the first anniversary of Orlando Zapata's death. In February 2011, the Cuban dissidents intended to organize a peaceful procession in Havana and all over the country; however, the state authority, which was afraid that the revolutions in the Arabian world would serve as a model for their country and the flame of dissatisfaction would break out, nipped the commemoration in the bud. Days before the planned demon- strations, those people who were thought to participate in the demonstrations were arrested one after the other; many of them were injured in prison. The regular procession of the group "Ladies in White" was disrupted by the throwing of eggs and stones, committed by hundreds of demonstrators in favour of the present political system. Groups from the governing party injured many journalists and human right activists. After the anniversary, more than two hundred dissidents were discharged.

Finally, Guillermo Farinas had to wait three years, until he could receive his exit visa to collect his prize, on the 3rd of July 2013, in Brussels from Gianni Pittella, European Parlia- ment Vice-President who presided at the award ceremony. (EP News, 2013)

7 http://eeas.europa.eu/cuba/index_en.htm (downloaded: 0508 2013)

SZABÓ Máté Csaba: The Representation of Human Rights and Economic Positions in Cuba

\section{Summary}

Although Cuba is considered a country that belongs to the sphere of interest of the United States, due to the political tensions between the two countries, the member states of the Eu- ropean Union have built up a significant economic position in the island.

Besides the deepening economic positions the European Union wishes to stand for the fundamental rights and values of the members states. To assist the democratic transition, to widen human rights, and to restore the rule of law, Brussels pays special attention to the op- position movements in the communist island.

To this end, the Parliament of the European Union awarded a Cuban dissident the Sakharov Prize for Freedom of Thought, and remarked that Cuba still has a long way to go until the normalization of human rights.

\section{References}

AARMS ANDÉERL13)'Á. (2004): The History of Cuba (Kuba története), Budapest: Akkord Kiadó 309

BBC (2010): Cuban prison hunger striker Orlando Zapata Tamayo dies, In. BBC News, London: BBC News http://news.bbc.co.uk/go/pr/fr/-/2/hi/americas/8533350.stm (downloaded: 0508 2013)

BUZÁS S. (2002): Cuba: Forced Reforms, Success, and Stalemate (Kuba: Kényszerü reformok, siker és megtorpanás), Budapest: MTA Világgazdasági Kutatóintézet

EUROPEAN PARLIAMENT NEWS (2013): Guillermo Fariñas receives his Sakharov Prize, Brussels: EP News, Press Unit http://www.europarl.europa.eu/news/en/pressroom/ content/20130701IPR14773/html/Cuban-dissident-Guillermo-Fari\%C3\%B1 as-to-receive2010-Sakharov-Prize-in-person (downloaded: 0508 2013)

EUROPEAN UNION (2011): Statement by the High Representative, Catherine Ashton, on the release of political prisoners in Cuba, Brussels http://www.consilium.europa.eu/uedocs/ cms_data/docs/pressdata/EN/foraff/120282.pdf (downloaded: 0508 2013)

LATELL, B. (2008): Cuba after Fidel Castro (Kuba Fidel Castro után), Budapest: HVG Könyvek LEONARD, T. M. 
(2004): Fidel Castro: A Biography, Santa Barbara: Greenwood Publishing SWEIG, J. E. (2009): Cuba - What everyone needs to know, Oxford: Oxford University Press

The Constitution of the Republic of Cuba, 1976 (as Amended to 2002) http://www.constitutionnet. org/vl/constitutionrepublic-cuba-1976-amended-2002 (downloaded: 0508 2013)

THE COUNCIL OF THE EUROPEAN UNION (1996): Council Regulation (EC) No 2271/96 of

22 November 1996, In. Official Journal L 309, 29/11/1996, pp. 0001 - 0006

http://eur-lex.europa.eu/LexUriServ/LexUriServ.do?uri=CELEX:31996R2271:EN:HTML (downloaded: 0508 2013)

WAŁĘSA, J. (2010): Cuba: EPP Group considers there are no reasons to change EU's policy towards the island, Brussels: EPP Group Press Service http://arc.eppgroup.eu/press/showpr.

asp?prcontroldoctypeid=1\&prcontrolid=9041\&prcontentid= 15622\&prcontentlg=en (downloaded: 0508 2013) 